\title{
The Impact of Architectural Design of Shopping Malls on Consumer Behaviours:
} A Case of Konya

Bilgehan Yılmaz Çakmak*

\section{Abstract}

Subject of consumer behaviours has been critical importance for business platform and related disciplines from past to present. Being able to understand consumer behaviour and identify strategies in this direction have become the most important condition for survival in competitive conditions. Many researchers produce new studies in order to understand and direct consumer behaviours more accurately. In time, researchers have elaborated these studies and have begun to link various disciplines such as law, economics, geography, architecture with consumer behaviour. In this study, it is aimed to determine the relationship between consumption concept and architectural discipline. Design criteria that increase and decrease consumption preference and quantity have been investigated by determining the extent to which the interior and exterior architecture affected the consumption habits.

Method: In this study, based on the literature, a conceptual survey of the daily shopping malls has been conducted from past to present. The basic literature is based on classification and description. By the determined hypotheses, observations, researches and surveys are conducted in the shopping centers located in Konya. Findings are tabulated and compared by morphological analysis technique. Survey data is analysed by SPSS
Keywords: Shopping malls, architectural design, consumer preferences, consumer behaviors.

*Asst Prof. Dr. Faculty of Architecture, Konya Selcuk University, Konya, Turkey. E-mail: cakmakbilgehan@gmail.com Orcid ID: http://orcid.org/0000-0003-41990648

** MA, Social Sciences Institute Business Education, Production Management and Marketing Science

E-mail: cihangiryilmaz@hotmail.com Orcid ID: http://orcid.org/0000-0001-52283864 
program. In these analyses, differential hypothesis tests (Independent Two Sample T Test, One Way ANOVA Test) and relationship hypothesis tests (Pearson Correlation Coefficient) are used.

Result: As a result, it has been found that the effect of interior and exterior architectural design of shopping centers on consumer behaviour is related to preferences, demographic data and consumer behavior. The results of the questionnaire application are influenced by the architectural design of the shopping centers, the amount of consumption and consumer behaviour. Therefore, the relationship between architectural design and consumer behaviour for shopping malls should be considered as an important factor in planning

\section{INTRODUCTION}

All living creature has to consume certain resources in order to meet its basic needs and to maintain its life. We see that diverse needs and products are added to the concept of time consumption when we look at the history of daily humanity from past to present as well as vital needs such as water, food, and housing. The transition from individuality to collective life has brought new needs, the development of cultures, industrialization and technological advances have consistently provided new needs and offered different products to people to be consumed. The effects of this change and consumption habits, consumer behaviours, factors that affect consumer behaviour have constantly changed. In terms of companies, this change has become the first condition to keep up with the competition and to set the marketing strategies in line with the ever changing needs and demands of the consumers.

Studies on consumer behaviours, which are the most basic aspects of marketing discipline, have shown that consumer behaviour is related to many different disciplines (economy, architecture, sociology, law, etc.). In other words, all disciplines have studied consumer behaviours from a different point of view and investigated their effects on their own fields.

Consumption habits, which are constantly changing day by day from past to future, have changed in consumption places. In the old ages, in the hans, bazaars, agoras, shopping places have been replaced by modern bazaars, supermarkets and shopping centres. These modern consumption spaces that emerged with the aim of enabling consumers to reach the products and services more easily and faster have become shopping centres that have differentiated over time and provide the opportunity to meet the spectacular and diverse needs spreading over large areas with the support of technology. As of the second half of the 20th century, the number of shopping centres in the world, which have been 
rapidly increasing, has become widespread, and especially the purchases of final consumers have begun to gather in these centres. Shopping centres that started opening even in some places, has made the need to differentiate by the effect of competition and the designers had to design different projects on the subject such as gigantic buildings in large square meters, aesthetically pleasing and impressive exterior designs, large landscaping areas, and interior designs providing comfort inside.

In this study, it is aimed to investigate consumption concept, consumer behaviours, shopping centers and architectural designs and evaluation the effects of these designs on consumer behaviour.

\section{Consumption and Consumer Concepts}

The concept of consumption has been subject to many researches from the past to present. Basically consume concept means finishing or destroying but it gains a broader meaning and developed over time. Researchers from different disciplines have studied this concept and different definitions have emerged about the concept of consumption. For example; Karalar (2002) made a definition about consumption like; "in order to meet the needs and requests of goods and services produced to be used by people", the definition that Odabaşı (2009) makes is; it's an ongoing process from birth to death which a product or service is searched, purchased, used or destroyed to satisfy certain needs. Another definition about consumption is made by Torlak (2000) which is; "legitimate whether or not one is needed, these needs to be satisfied, or spent on imported material and spiritual values be mobilized afford to spend".

From all these definitions, it is possible to make a definition as "to use goods or services for consumption by the individuals or organizations to remove the necessities from the way".

When societies are examined, it is seen that people come to the world as a consumer and continue to play the role of consumer constantly in various fields throughout their entire life. Especially today, with the increase of product and service variety, it is seen that every moment we have passed through a consumption activity and become insatiable consumers.

\section{Consumer Behaviours and the Factors Affecting Consumer Behaviours}

There are different definitions for consumer behaviours. It is the process in which decisions such as which product, who, (Orhan, 2002). Consumption is a process which has the methods used when deciding consumption, the attitudes formed with internal or 
external factors against the product, selecting and using the product.

The factors that affect consumer behaviour and the dimensions of these effects are the most important issues to be investigated. This issue, which is at the core of marketing activities, is one of the most important elements in determining the direction of consumer demands.

Although many models of consumer behaviour have been developed, there is no model that can fully explain consumer behaviour. The common feature of existing models is that they accept that consumer behavior is influenced by a number of factors (İslamoğlu, 2002). The following table shows the factors affecting consumer behaviours.

Figure 1. Factors affecting consumer behaviours (İslamoğlu, 2003: 52-53).

\begin{tabular}{|c|c|c|c|}
\hline \multicolumn{5}{|c|}{ The Factors Affecting Consumer Behaviors } \\
\hline Personal Factors & Socio-cultural Factors & Economic Factors & Psychological Factors \\
\hline $\begin{array}{c}\text { Age } \\
\text { Gender } \\
\text { Job } \\
\text { Education Status } \\
\text { Marital Status } \\
\text { Income Rate }\end{array}$ & $\begin{array}{c}\text { Family } \\
\text { Caste } \\
\text { Groups } \\
\text { Culture }\end{array}$ & $\begin{array}{c}\text { Monthly Personal Income } \\
\text { Fanily Income } \\
\text { Transportation prizes } \\
\text { Consume amount rate }\end{array}$ & $\begin{array}{c}\text { Motivation } \\
\text { Perception } \\
\text { Learning } \\
\text { Faith and Attitudes }\end{array}$ \\
\hline
\end{tabular}

From past to present, working in the field of consumer behaviour, the researchers examined the factors that affect consumer behaviour according to their own disciplines. Today the subject of consumer behaviour, economics, business, sociology, psychology, biology, philosophy, anatomy, architecture, mathematics, statistics, geography, anthropology, and many different disciplines such as law, benefit actively (Koç, 2012).

\section{The Relation Between Shopping Mall Architecture and Consumer Behaviours}

The fact that most of the consumption is done in the shopping centers and the shopping centers are the most visited places outside the residence and the work place shows the importance of the shopping concept and the shopping centers in the lives of the people and the shopping structures are shaped in the direction of the society needs and requests. The search for a place where people can meet the need for shopping as well as travel and enjoy in their spare time or leisure time plays an important role in shaping shopping centers (Uslu, 2006).

The relationship between architectural discipline and consumer behaviour is mainly concerned with the development and implementation of general and specific designs of shopping malls, stores and supermarkets. The design and implementation of shopping centers and units in a way that allows customers to buy more and more products and services in a more convenient way 
The Impact of Architectural Design of Shopping Malls on

Consumer Behaviours: A Case of Konya

requires a combination of consumer behaviour and architectural knowledge (Koç, 2012).

\section{Shopping Malls}

Shopping malls; Is a shopping unit created by specially designed shops and stores with comfortable working environments and technical spaces for employees at the shopping mall that provide customers with the convenience of shopping, enjoying, having fun and resting, meeting the needs of customers in addition to being able to meet their shopping needs (Uslu, 2006).

Shopping Centers are large spaces that combine consumer areas such as large national or local markets, multi-department stores, restaurants, cafes. With this feature, the different needs of consumers, by saving time on places which are easily and lets meet. For example, a family visiting a shopping mall can visit different stores to meet their children's clothing needs, shop for their homes, and return to their homes by eating dinner under the same roof. İn this way, shopping centers that offer more and easier shopping for people have a huge share, especially in retail consumption.

\section{The Architecture of Shopping Centers}

The development of a shopping mall requires certain steps. These steps are a mixture of economic, financial, commercial and design decisions. The analysis of the market, the political and legal situation, architectural design, tenant structure and choice, traffic planning, energy use and protection of the environment, advertising and public relations constitute the sub-details of the mixture (Yılmaz, 2008).

In the shopping centers, it is firstly to determine the criteria function areas that should be evaluated in terms of architecture. It is possible to examine the functional areas, the sales spaces, the unifying qualities, the circulation system, and the parking spaces where the vehicles of the persons coming to the building can leave. In addition to this, the standing of the structure is determined and investigated as the functions forming the whole of the structure in the visual arrangements which we call the characteristics of the carrier system and the aesthetics (Yllmaz, 2008).

The shopping malls are designed to ensure that the architectural consumer remains in these isolated small cities for a long time. The outside of the building does not give information about what is inside, the inside is not connected to the outside. This is the result of time-space separation. The breakup of the relationship with the outside is also the separation from the outside time-space relations. The time out of the rhythm has its own internal rhythm. 
As size increases, is moved into the city shopping malls, selfsufficient, and the interior has a great importance in this case, a new format is born publicity. Light stability eliminates the difference day and night. It's always daytime, time is up. When everything is under the same roof, a self-sufficient new urbanpublic space emerges. The fact that there are no large transparent openings to the outside opens the relation between the environment and the internal rules. Thus, the outside of the room becomes a "crust" surrounding it (Yırtıcl, 2002).

The interior of the shopping center must also be designed to support the exterior architecture. The layout of the shops and service departments in the shopping mall should be such as to provide the continuation of the outside influence. For example, the color of the store exterior ceiling and the material used leave different effects on consumers. It can be the first or even the only clue that most of the storefront's external counterparts will be related to the store (Arslan, 2004) or store shopping can be arranged as the perimeter of a supportive or restrictive. The environmental-psychological environment is brought together by the consumer in a meaningful sense, and this meaning influences the shopping attitude experientially (Argan, 2007).

\section{Case Study}

Shopping centers have been opened in Konya since 2000 and they are being used actively. Within the scope of the thesis study, four major shopping centers in the center of Konya will be examined. In traditional classification; The four malls that are the subject of study are included in the "regional modern shopping malls" group.

Konya Kulesite, Kentplaza, M1 Konya and Novada, are the most used shopping centers in terms of their location, size and possibilities. In terms of construction year, M1Konya was first built, followed by Kulesite, Kentplaza and Novada shopping centers. The general characteristics of these shopping centers are given in the table below; 
The Impact of Architectural Design of Shopping Malls on

Consumer Behaviours: A Case of Konya
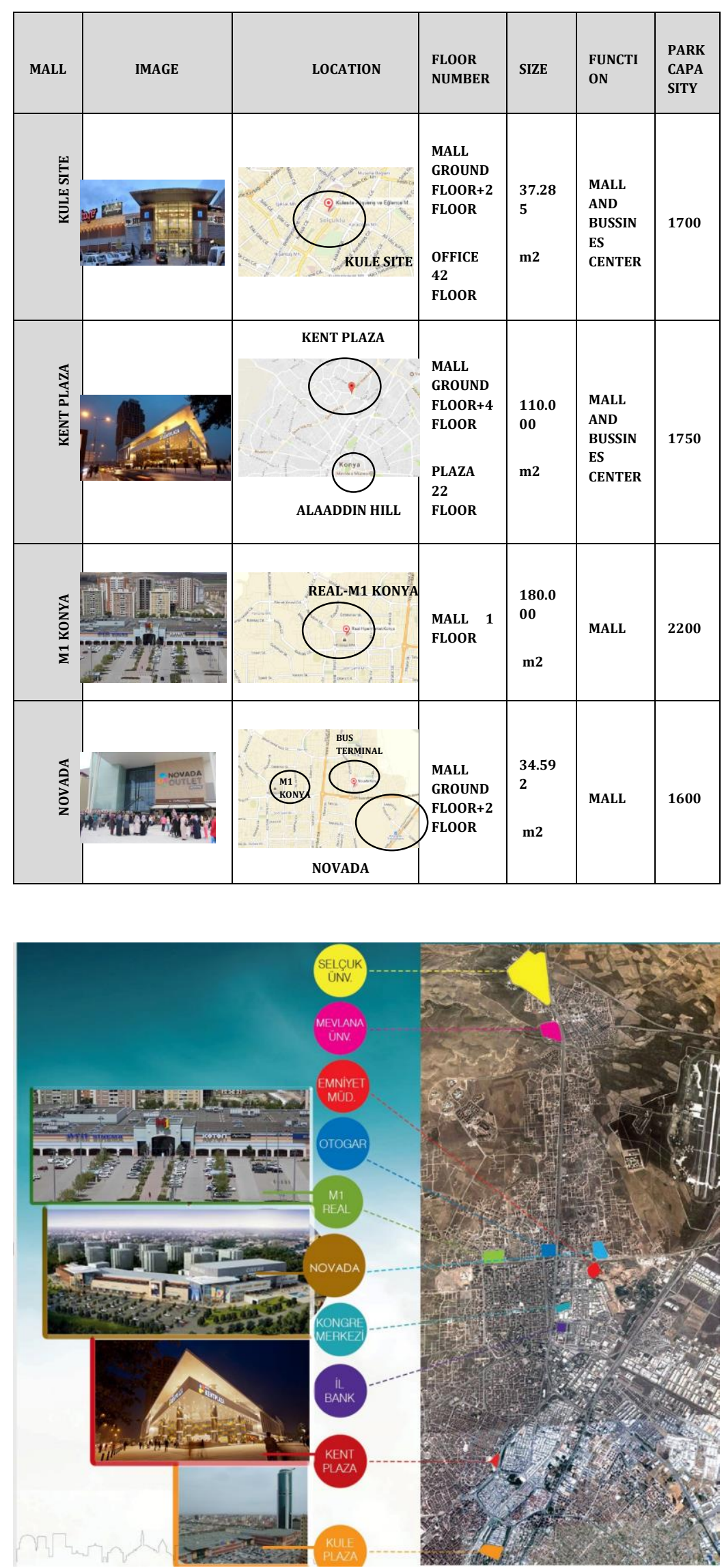

Figure 2. General characteristics of these shopping centers

Figure 3. Locations and relations of shopping centers 


\section{Kule Site Shopping Mall}

Kule Site shopping Mall is one of the major malls in Konya. It was built in June 2004 by Seha. 28 thousand people visit on average every day during the week, also 45 thousand people visits on weekends. It is the center for social and cultural life with its rentable area of $44,570 \mathrm{~m}^{2}$ with a $100 \%$ occupancy rate. (Topçu, 2011).

Figure 4. The atrium of Kule Site shopping mall

Figure 5. The floor plans of Kule Site shopping mall

Figure 6. The layout of circulation market and shops in Kule Site shopping mall
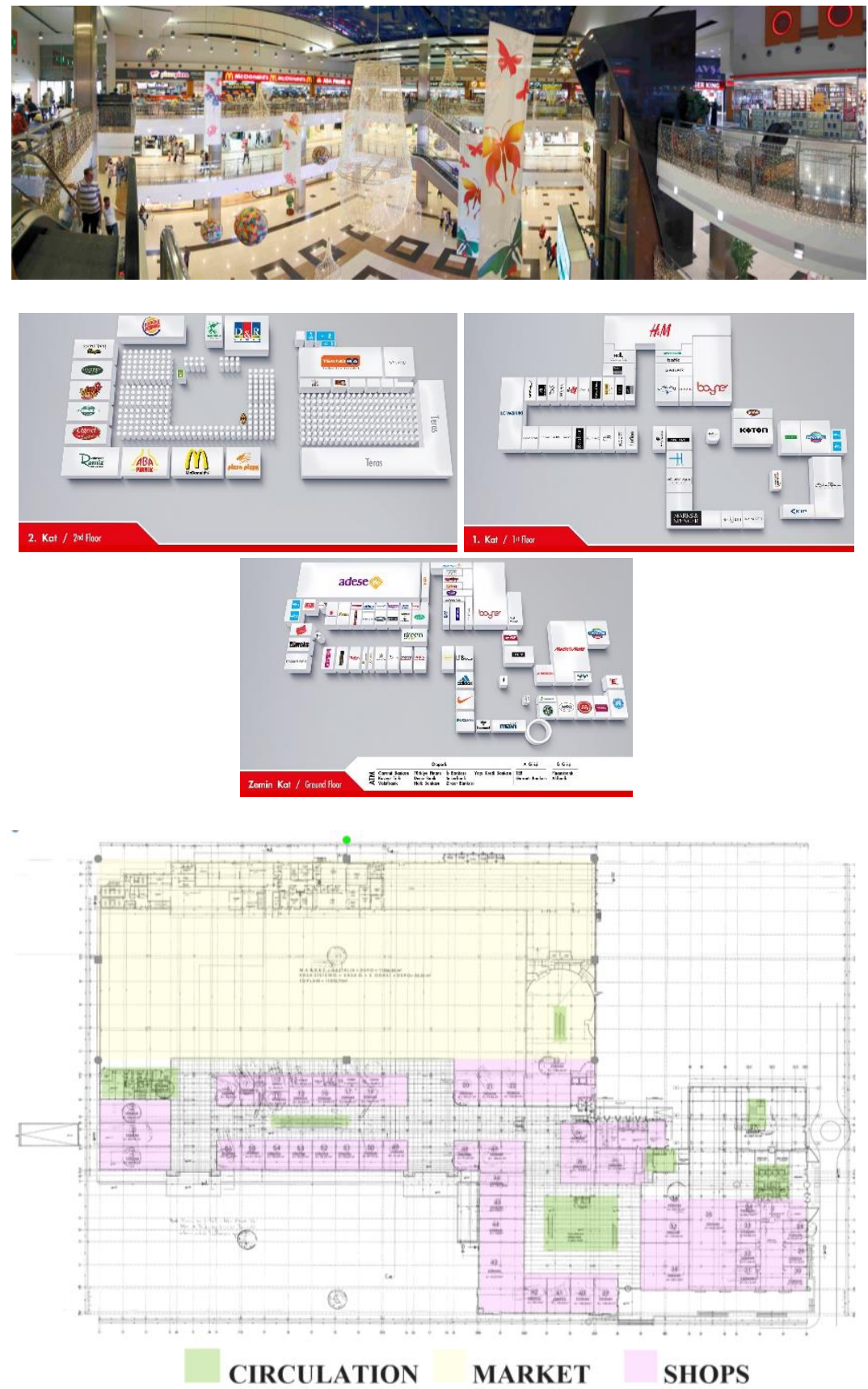

\section{Kent Plaza Shopping Mall}

Kent Plaza Shopping Mall was built in November 2012 and it is the only international shopping mall in Konya. Kentplaza, located in the Kentplaza Complex, a candidate for being one of the new iconic buildings of Konya, has an area of approximately 110 thousand 
The Impact of Architectural Design of Shopping Malls on Consumer Behaviours: A Case of Konya

square meters with the tower comprising the office block. Kentplaza Shopping Center is the shopping and living center with the biggest brand in Konya. More than 60 brands, including national and international brands, will be serviced in Kentplaza for the first time in Konya where 160 stores are located.
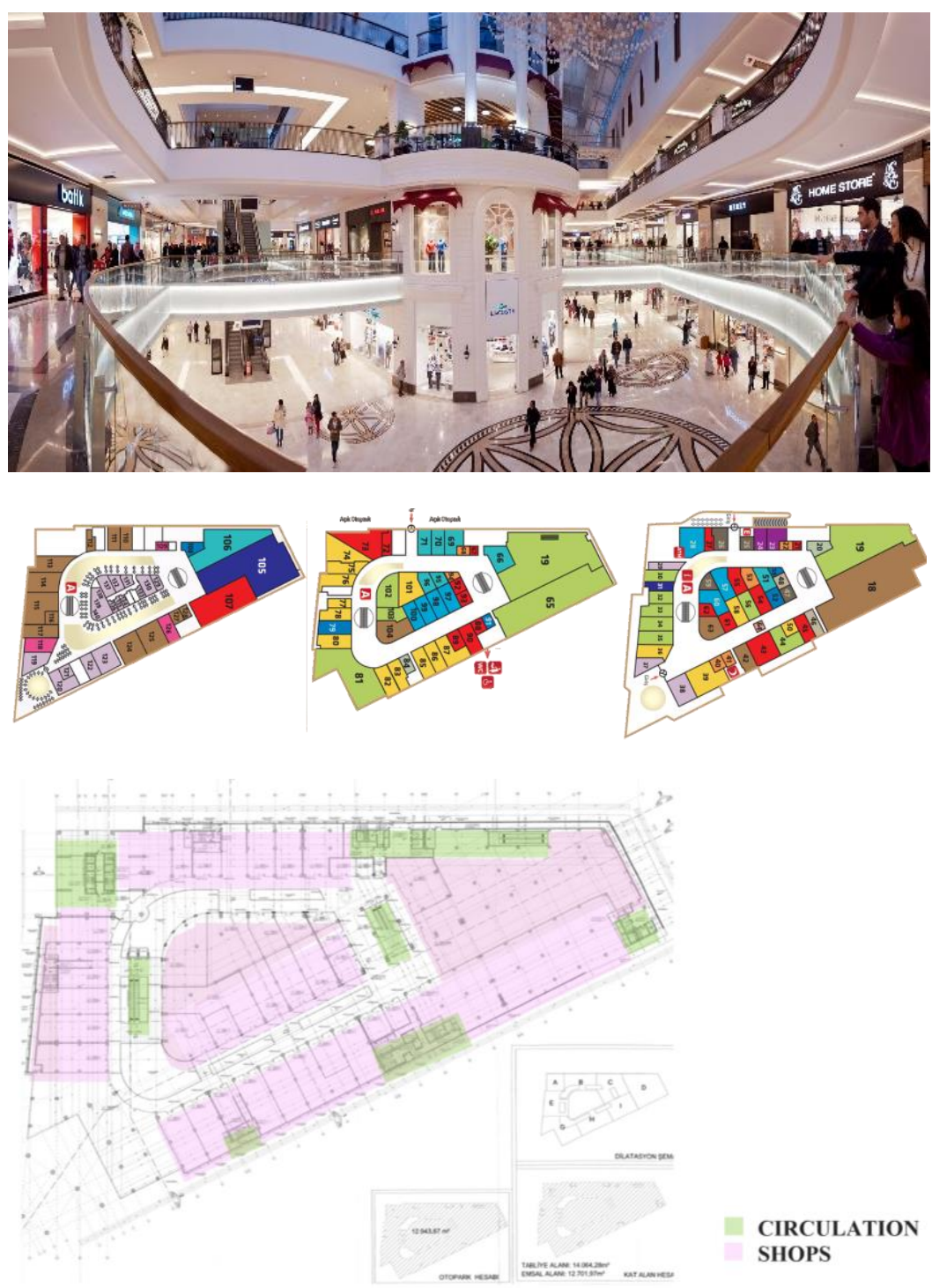

\section{M1 Konya Shopping Mall}

It was opened in 2002 around the Konya national bus terminal. M1 Konya Shopping Center, which operates as a one storey building, is located on a large area of $180.000 \mathrm{~m} 2$. In front of the Shopping Center, there is an open car park with 2200 cars and a large amusement park next to this area. Storey building, is located on a large area of $180.000 \mathrm{~m} 2$.
Figure 7. The atrium of Kent Plaza shopping mall

Figure 8. The floor plans of Kent Plaza shopping mall

Figure 9. The layout of circulation and shops in Kent Plaza shopping mall 
Figure 10. The atrium of M1 Konya shopping mall

Figure 11. The floor plan of M1 Konya shopping mall

Figure 12. The layout of circulation market and shops in M1 Konya shopping mall

Figure 13. The atrium of Novada shopping mall.
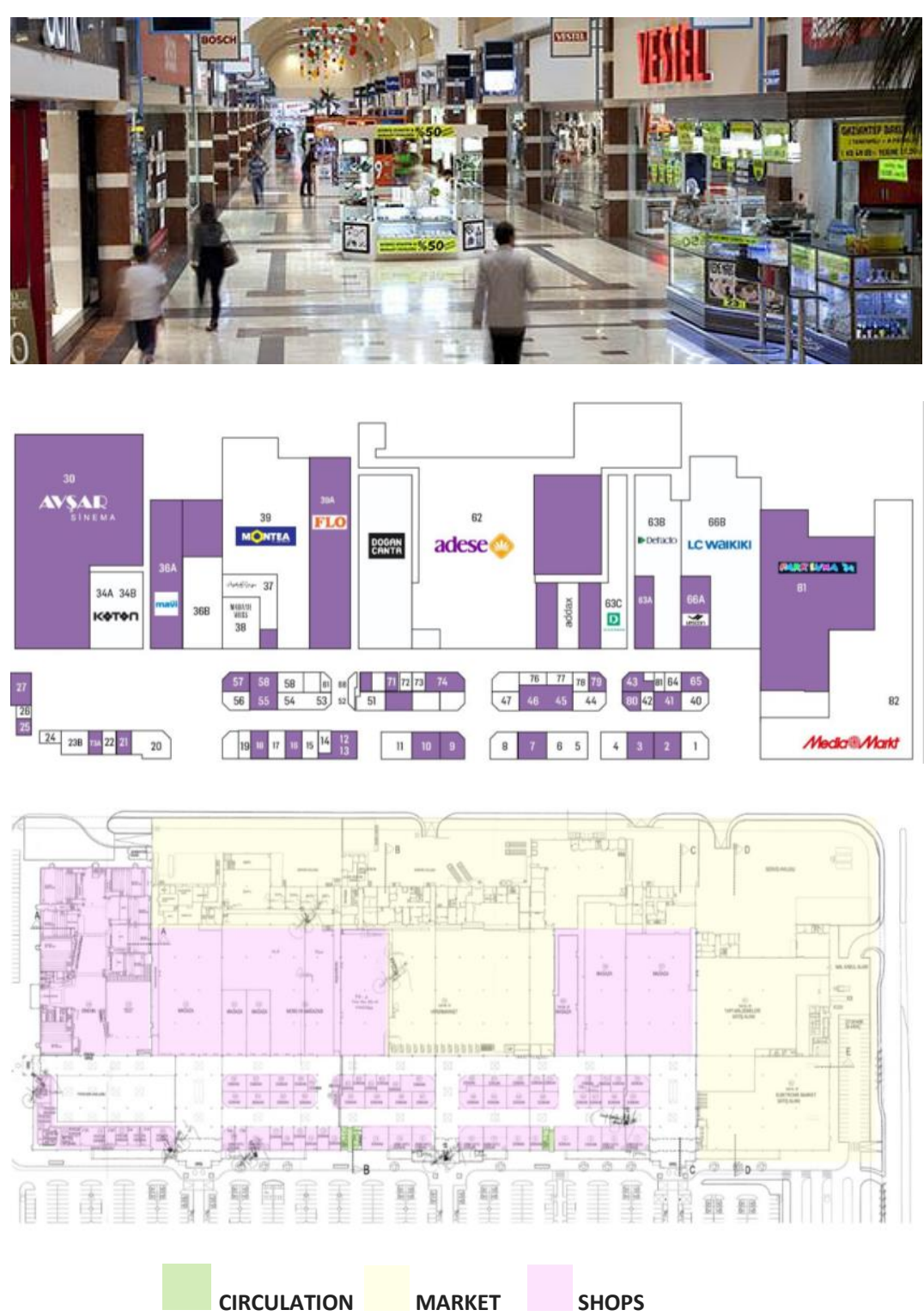

\section{Novada Shopping Mall}

Novada Shopping Center, which operates in 2015, is the city's first outlet mall. The shopping center, which serves with 127 stores on a $34.592 \mathrm{~m} 2$ leasable area, has a parking capacity of 1600 vehicles including indoor and outdoor.

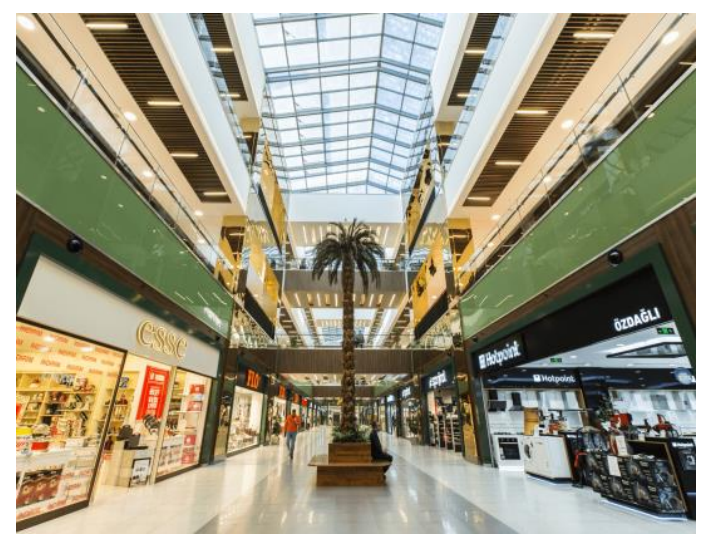



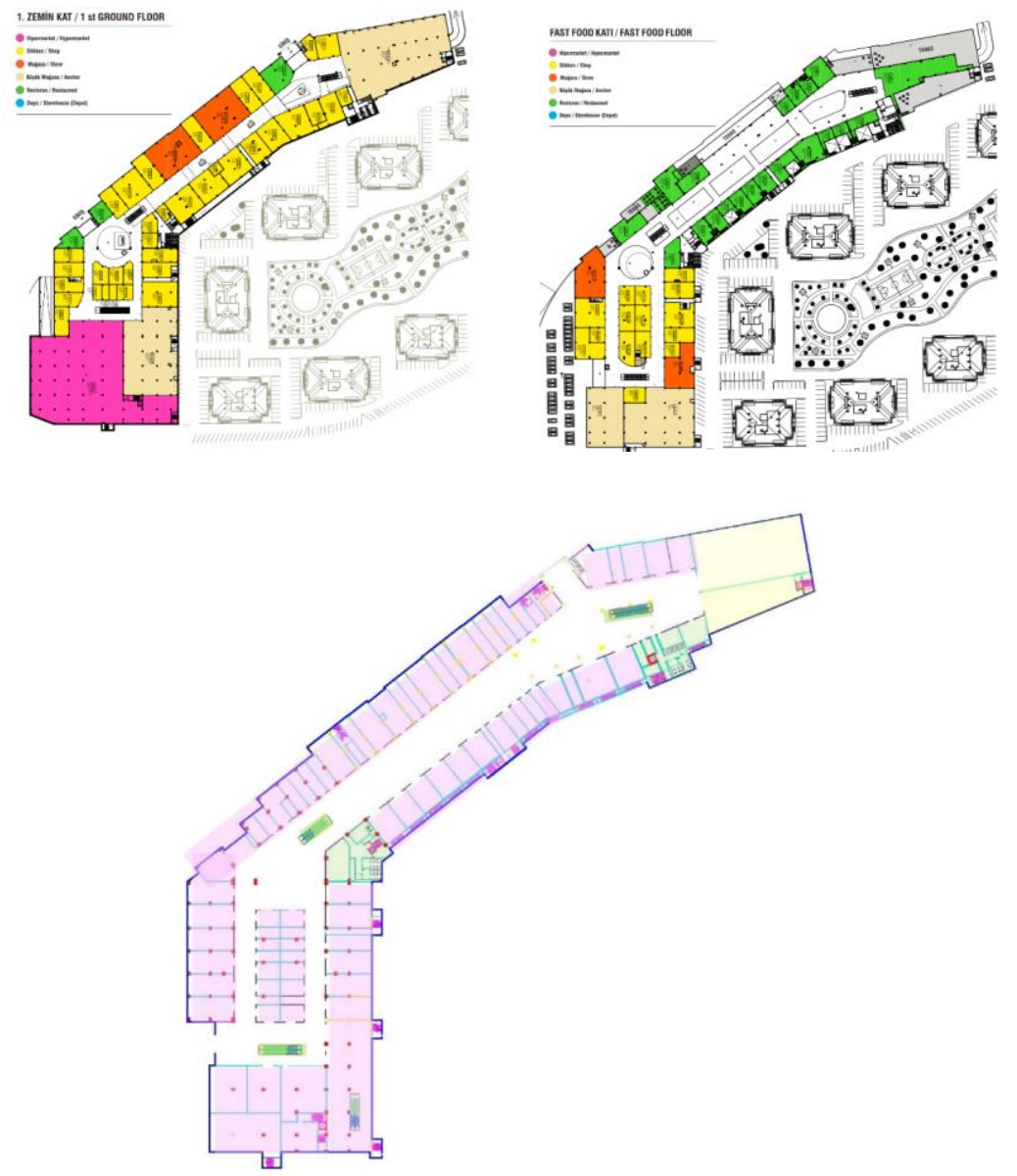

CIRCULATION

MARKET

SHOPS

\section{Survey Study}

A survey study conducted including the malls located in Konya, Kentplaza, Kulesite, M1 Konya and Novada shopping malls. The survey was conducted with 100 participants. Careful attention has been paid to selecting the consumers participating in the survey study in different occupational groups, different age groups and different socio-economic levels. In addition, the questionnaire was conducted on weekdays and weekends, at different times of the day, and was sensitive about the homogeneity of the study. Participation in the study; shopping habits, reasons for visiting shopping centers, preferences for shopping centers, and the effects of interior and exterior architectural designs.

Analysis of the data was done with SPSS 22 program and it was worked with $95 \%$ confidence level. An analysis of the relationship between shopping center architectural design elements on the shopping center preference effect and the consumption effect score was analyzed by the nonparametric Spearman correlation test (Yllmaz 2017).
Figure 14. The floor plans of Novada shopping mall.

Figure 15. The layout of circulation market and shops in Novada shopping mall. 
Figure 16. Findings about usage period of shopping centers, (Yllmaz 2017).

\begin{tabular}{|c|c|c|c|}
\hline & & $\mathrm{n}$ & $\%$ \\
\hline \multirow{2}{*}{ GENDER } & \multirow{2}{*}{$\begin{array}{l}\text { WOMAN } \\
\text { MAN }\end{array}$} & 249 & 62,3 \\
\hline & & 151 & 37,8 \\
\hline \multirow{5}{*}{ AGE } & under 25 age & 113 & 28,3 \\
\hline & 25-35 age & 143 & 35,8 \\
\hline & $36-45$ age & 86 & 21,5 \\
\hline & 46-55 age & 42 & 10,5 \\
\hline & above 56 age & 16 & 4,0 \\
\hline \multirow{2}{*}{ MARITAL STATUS } & \multirow{2}{*}{$\begin{array}{l}\text { single } \\
\text { married }\end{array}$} & 231 & 57,8 \\
\hline & & 169 & 42,3 \\
\hline \multirow{4}{*}{ EDUCATION STATUS } & \multirow{4}{*}{$\begin{array}{l}\text { primary education } \\
\text { high school } \\
\text { license } \\
\text { graduate }\end{array}$} & 31 & 7,8 \\
\hline & & 117 & 29,3 \\
\hline & & 240 & 60,0 \\
\hline & & 12 & 3,0 \\
\hline \multirow{5}{*}{ INCOME STATUS } & \multirow{5}{*}{$\begin{array}{l}\text { under } 1400 \mathrm{TL} \\
1400-2799 \mathrm{TL} \\
2800-4199 \mathrm{TL} \\
4200-5600 \mathrm{TL} \\
\text { above } 5600 \mathrm{tl}\end{array}$} & 116 & 29,0 \\
\hline & & 198 & 49,5 \\
\hline & & 58 & 14,5 \\
\hline & & 15 & 3,8 \\
\hline & & 13 & 3,3 \\
\hline \multirow{5}{*}{ WORKING STATUS } & \multirow{5}{*}{$\begin{array}{l}\text { Student } \\
\text { Paid employee } \\
\text { Self-employment } \\
\text { Retired } \\
\text { Unemployed }\end{array}$} & 114 & 28,5 \\
\hline & & 243 & 60,8 \\
\hline & & 17 & 4,3 \\
\hline & & 19 & 4,8 \\
\hline & & 7 & 1,8 \\
\hline \multirow{6}{*}{$\begin{array}{l}\text { How often do you go } \\
\text { to shopping center }\end{array}$} & \multirow{6}{*}{$\begin{array}{l}\text { Every day } \\
\text { Once a week } \\
\text { Once in } 15 \text { days } \\
\text { Once a month } \\
\text { If neccessary }\end{array}$} & $\mathrm{n}$ & $\%$ \\
\hline & & 18 & 4,5 \\
\hline & & 115 & 28,8 \\
\hline & & 89 & 22,3 \\
\hline & & 40 & 10,0 \\
\hline & & 138 & 34,5 \\
\hline \multirow{5}{*}{$\begin{array}{l}\text { Which transportation do you } \\
\text { use to reach the shopping } \\
\text { center? }\end{array}$} & \multirow{5}{*}{$\begin{array}{l}\text { personal transport } \\
\text { public transport } \\
\text { taxi } \\
\text { pedestrian } \\
\text { services }\end{array}$} & 230 & 57,5 \\
\hline & & 115 & 28,8 \\
\hline & & 7 & 1,8 \\
\hline & & 43 & 10,8 \\
\hline & & 5 & 1,3 \\
\hline \multirow{4}{*}{$\begin{array}{l}\text { how long do you spend in the } \\
\text { shopping center }\end{array}$} & less an hour & 33 & 8,3 \\
\hline & $1-3$ hour & 303 & 75,8 \\
\hline & 4-6 hour & 60 & 15,0 \\
\hline & all dav & 4 & 1,0 \\
\hline
\end{tabular}

Analysis of The Relationship Between The Effect of Shopping Center Architectural Design Elements on Shopping Center Preference and The Effect of Consumption Quantity

According to data analysis,

There is a positive positive correlation between shopping center architectural design elements and shopping center architectural design elements $(p<0,05$ rho $=, 756)$.

There is a statistically significant difference between different age groups in terms of the consumption amount of shopping center architectural design elements $(p<0,05)$. 
When the average of the points is examined, it is seen that the shopping center architectural design elements have the greatest effect on the consumption amount, whereas those aged 25 years or less have the effect at least between the ages of 36-45.

According to the Bonferroni-adjusted Mann Whitney test for binary comparison, shopping center architectural design elements have a greater impact on consumption than those aged 25-35 and 36-45 years old and under.

There is a statistically significant difference between shopping center architectural design elements and shopping center preference among groups with different education status ( $p$ $<0,05$ ). When the rank order of the points is examined, it is seen that the shopping center architectural design elements have the greatest effect on the preference of the shopping center in the graduate graduates, but there is an effect at least at those who graduated from primary education.

Bonferroni corrected Mann Whitney test for dual comparison According to those who graduated from high school and primary school graduates, According to those who have graduated from primary schools in the undergraduate and high school graduates, shopping center architectural design elements have more influence on shopping center preference.

There is a statistically significant difference between shopping center architectural design elements and shopping mall preference among groups with different income status. $(\mathrm{P}<0.05)$. When the point average is examined, it is seen that the shopping center architectural design elements have the greatest effect on shopping center preference while the revenue is less than 1400 TL.

\section{Conclusions and Recommendations}

Human beings, in all stages of life from the first ages to the present days lives in an endless consumption. Consumer actions, which has been unconsciously started from the first moment of life, continues until the last breath is given. While the basic necessities such as food and shelter, which are necessary for the maintenance of life, constitute the major consumer goods, today's differentiated and diversified needs have made the concept of consumption much more comprehensive. In the past, the only option for meeting the need for food in the past is the opportunities offered by nature. Today, thousands of alternatives can easily be reached in restaurants, cafes, markets to meet the same needs. The manufacturing facilities that industrialization 
and technology brings together have enabled the provision of innumerable options in all matters for people to consume.

These changes in the concept of consumption have made it possible to create a highly competitive environment for producers and sellers. Every product and service produced is among many options available to consumers and has to complete with similar products and brands. This has led marketing departments to seek out different ways to stand out from the competition and to be different from others, and to investigate consumers preferences, shopping habits, and purchasing motivations. There are many researches on consumer behaviors today. These studies have shown us that consumer behaviors should be studied together with basic human behaviors. Another result emerging from the researches is; the only way to build a successful marketing strategy in terms of brands is the accurate and detailed analysis of personal, psychological, socio-cultural and economic factors affecting consumer behavior. Markets that conduct these analyzes will be able to create more effective and efficient marketing strategies.

The evolution of consumption has created changes simultaneously in consumption spaces. In the past, arastas, bedestens, caravanseraies, bazaars, while today, these places are replaced by modern shopping centers. These shopping centers, which emerged in the early 20th century, are increasing day by day and differentiated. Today, there are many shopping mall types that vary according to their characteristics.

Today's shopping centers have become centers of life built on large square meters, with many different functions inside, where people can meet their needs like clothing, market, food, and where people have the opportunity to socialize. These centers offer different architectural designs both indoors and outdoors in order to be places that consumers prefer.

In the questionnaire survey, shopping center's architectural design was divided into 'interior architecture design' and 'outdoor architecture design', and the effects of these elements on consumer behavior and consumption amounts were investigated.

According to the results of the research;

- The effect of the outdoor architectural design of the shopping centers on the consumer behavior is related to the consumers, 
The Impact of Architectural Design of Shopping Malls on

Consumer Behaviours: A Case of Konya

- The effect of outdoor architectural design of shopping centers on consumer behavior is related to consumers' preferences of shopping center,

- The effect of the interior design of the shopping centers on the consumer behavior is related to the consumers,

- The effect of interior design of shopping centers on consumer behavior is related to consumers' preference for shopping center,

- The effect of the outdoor architectural design of the shopping centers on the amount of consumption differs according to age groups (under 25 years and between $36-45$ years),

- The effect of the outdoor architectural design of the shopping centers on the amount of consumption differs according to the income situation (under $1400 \mathrm{TL}$ and over $5600 \mathrm{TL}$ ),

- The effect of the interior design of the shopping centers on the amount of consumption differs according to the education level (High School Graduate and Undergraduate Graduate), results, have been achieved.

It is seen that the results of the questionnaire application are influenced by the architectural design of the shopping centers, the amount of consumption and consumer behavior. Therefore, the relationship between architectural design and consumer behavior for shopping malls should be considered as an important factor in planning.

Research has been conducted on the impact of architectural design of shopping centers on consumer behavior. Within the scope of this subject, shopping centers and stores on the streets can be added to create a useful work by interpreting the effects of lighting, smell and music on consumer behaviors and the effect of architectural design.

\section{REFERENCES}

Argan, M. (2007). Entertainment Marketing, Ankara: Detay Publishing, 25-80.

Arslan, F. M. (2004). Marketing Atmosphere Derin Publishing, İstanbul

İslamoğlu, H. (2002). Consumer Behaviours. Beta Publishing, İstanbul

Karalar, R. (2002). General Management. Eskișehir: Anadolu University. 
Koç, E. (2012). Consumer Behaviours and Marketting Strategies, Seçkin Publishing, Ankara

Odabaşı, Y. (2009). Culture of Consuming: 'From Convinced Society To Consuming Society. Sistem Publishing, İstanbul

Orhan, İ. (2002). Investigation of Purchased Products in Relation to Gender and Gender Roles, Ankara University, Social Science Instution, Physicology Master Thesis, Ankara.

Topçu, K. (2011). An Evaluation on Shopping Places in Terms of Spatial Quality: A Comparative Analysis, PhD Thesis, The Graduate School Of Natural And Applied Science of Selçuk University, Konya.

Torlak, Ö. (2000). Consumption: Communal Transformation of Personal Functions. İnkılâb Publishing, İstanbul

Uslu, Z. (2006). Development of shopping centers: Konya example. University of Selcuk, Institute of Science, Konya

Yllmaz C. (2017). The effects of Architectural Design to Consumer Behaviors In Shopping Centers: Konya Example, Business Education Production Management And Marketing Science, Konya

Yllmaz, F. (2008). Marketing Consultancy in Shopping Center Design: Investigation in Kocaeli Provincial Center, Master Thesis, Yıldız Technical University, Istanbul.

Yirtıcl, H. (2002). Modern Capitalism and spatial organization. İstanbul Bilgi University Publishing, İstanbul

\section{Resume}

Bilgehan Yllmaz Çakmak works at Selcuk University, Faculty of Architecture, Department of Architecture as an Asst.Prof.Dr. She got her B.Sc in 2002 in Süleyman Demirel University, Msc in 2006 in Selcuk University and PhD in 2011 in Selcuk University on Architecture. She is interested in building design, accesiblity, pedestrian movements and user preferences. She has several courses about design, accesibility, marketting and communication in architecture.

Cihangir Yllmaz received bachelor's degree in business administration department of Selçuk University in 2005 and master's degree in production management and marketing at Selçuk University in 2017. Since 2000 he has worked in different cities and companies in the field of sales and marketing, mainly in shopping malls. Since 2014 he has been working as General Manager in Major Consulting. He provides training and consultancy services to the companies in the fields of sales, marketing, consumer behavior. 